\title{
Correlation Between Extreme Fandom and Homosexual Behaviors of Teenager Korean Bands Fans
}

\author{
Ambar Sulianti, Aa M Idharul Haq, Elvariana Valencia Arisanti, Wawan Hernawan \\ UIN Sunan Gunung Djati Bandung \\ Bandung, Indonesia \\ ambarsulianti@uinsgd.ac.id
}

\begin{abstract}
Social media observations indicate that adolescents who excessive adore their idol partners tend to have sexual orientation that leads to homosexuality. Women who love manga, anime, homosexual-themed novels are called fujoshi while men are called fudanshi. The purpose of this study was to find out whether idol worship rates had an effect on homosexual intense on adolescent fujoshi and fudanshi fans of Korean bands. This study is a cross sectional study of $\mathbf{8 1 5}$ adolescents fujoshi and fudanshi Korean band fans. Data was analyzed using Pearson correlation test. The results obtained from this study are idol worship show positively correlated with intense homosexuality in fujoshi and fudanshi fans of Korean bands $(p<0.05)$. Based on the research results, it can be concluded that higher idol worship rate makes higher homosexual intents on fujoshi and fudanshi Korean band fans. We suggest that fujoshi and fudanshi should control social media in order not to become a crucial part to influence their life. This research becomes basic for further research.
\end{abstract}

Keywords-idol worship; fujoshi; fudanshi; homosexual; adolescent

\section{INTRODUCTION}

Idolizing Korean band artists is quite evident among teenagers in Indonesia. Korean Pop music industry (K-Pop) is one of the biggest suppliers of the emergence of figures who became the idol of teenagers both girl bands and boy bands. They consist of a group of girl or boy with an attractive physical appearance and have good singing and dancing skills. The community is called members of the band. They become idols in the K-pop world and for those who idolize them are commonly called fans.

Originally, the word 'idol' has a false meaning of God [1]. In line with changing era, the idol context has shifted more and more to the human being who became the object of awe and wonder and the center of people's attention. This condition will lead to an idol as the center of pleasure, awe and amazement and, along the run, the idol will be worshipped.

There is a unique phenomenon of K-pop fans that is the behavior of pairing a K-Pop idol member with another member of the same band of the same sex. People who behave like them are known as Shipper. Ship is a situation where fans imagine a certain romantic relationship in some characters between fictional characters. Some may be original stories, others may be fan-only. Slash pairing is a state in which fans pair certain characters of the same gender. These attached characters are called OTP (One True Pairing). OTP are the characters paired by the shipper in the context of romantic relationships [2].

Although the installation of one idol with other idols is only the fans' desire, some shipper even believe that their idol is a homosexual actor. Sexual orientation is a feeling of sexual and emotional attraction to a particular gender. Sexual orientation is divided into three [3]: (1) heterosexual, thai is sexual attraction in different sex, (2) bisexual, that is sexual attraction to woman and man at the same time, and (3) homosexual, that is sexual attraction to the same sex Sexuality is a sexual activity perpetrated by a similar partner. Homosexuality is a romantic and / or sexual attraction or behavior between individuals of the same sex or gender. If the homosexual actors are male, they are called gay. Conversely, if the homosexual patients are female, they are called lesbian.

Shipper is a person who likes their idols to do or have relationships to the same sex. The fans are not happy and are not willing if their idol has relationship to the opposite sex. However, not all shipper experienced sexual orientation disorder or sexual identity disorder. This draws the researcher's attention to find out whether there is a relationship between the levels of shipper's fanaticism to the shipper's homosexual intensity.

\section{RESEARCH METHOD}

\section{A. Research Design}

The present study employed a quantitative correlation test design since it examined the relationship between variables in the collected data.

\section{B. Research Subject}

The population of the present study was the K-pop shipper fans who actively joined the shipper group on Facebook and Instagram. They consist of 814 people. Meanwhile, the 
research subjects were 670 active shipper people who are willing to be respondents.

\section{Research Variable}

Celebrity worship is conceptually defined as a form of a parasocial relationship in which a person becomes obsessed with celebrities [4] [5]. Celebrity Worship Fanaticism in this study was measured with a questionnaire that contains a statement of the behavior of an individual's obsession to always be involved in every life of a celebrity that is popular so that brought into the daily life of the individual.

The homosexual intense is an intense sexual stage addressed to one gender adapted from a scale made by Dr. Alfred Kinsey or often called the Kinsey Scale. The orientation scale of sexual orientation is 0 for exclusive heterosexuals, 1 for heterosexuals more prominent, homosexual sometimes, 2 for heterosexuals more prominent, homosexuals more than occasionally, 3 for heterosexual and homosexual balance, 4 for more prominent homosexuals, heterosexuals more than sometimes - sometimes, 5 for more prominent homosexuals, occasional heterosexuals, and 6 for exclusive homosexuals.

\section{Research Procedure}

The research used the following procedure: determining the assessment instruments, determining the subject, creating a form on Google drive and shortening links by using Bit.ly, spreading the link in social media (Instagram, Line, WhatsApp, and Facebook), downloading csv from Google drive result from Google form, analyzing items, retrieving, and analyzing data.

First, confirm that you have the correct template for your paper size. This template has been tailored for output on the A4 paper size. If you are using US letter-sized paper, please close this file and download the file "MSW_USltr_format".

\section{RESUlT AND DisCUSSION}

Subjects who filled in the questionnaires ranged from 11 years to 30 years, with the age mode of 17 years as many as 127 people (16\%). The K-pop group fans and their ages are presented on charts 1 and 2 .

The correlational analysis between the worship fanaticism and the intense homosexuality is presented in Table 1. The results of the study indicate the worst level of idol worship is borderline pathological, has the level of Pearson correlation that move more positive. Here can be concluded if borderline pathological is directly proportional to idol worship. This means that the worse level of idol worship then the intensity of homosexuality is also higher.

Based on the table, it can be seen that if the borderline has a value of 0.106 and 0.219 on a scale of 5 and 6 . Then it can be said if the extreme idol worship level is related to higher homosexual intensity. Sig. (2 tailed) on a scale of 5 and 6 in the table shows 0.13 and 0.00 . Since both are less than 0.05 it can be concluded if there is a significant relationship between extreme idol worship and high homosexual intensity.
Social media is a world that is not limited by time and space. Moreover, it does not have a specific rule. Excessive use of social media which becomes individuals' crucial part of life will gradually affect their personality. Basically, social media are made to connect with people, to get information and to disseminate it. The information widely spread will be seen by a lot of people and get "LIKE" response and, later, it will be possibly reposted. In fact, the information could be just fake news or a story. Alternatively, it is just a fantasy, or an assumption. However, participants who were involved the study were shipper; they made their own fantasies about their idols that are considered a belief. They themselves have a strong conviction to their beliefs, as well as to those idol couples.

Sexual orientation is caused by a complex interaction among environmental, cognitive, and biological factors. Sexual orientation is different from sexual behaviors; it relates to feelings and self-concepts. However, individuals can also show their sexual orientation in their observable behavior.

According to psychomotor theory, the mind-brain-body is a functional unitary unit, since mind does not stop working in brain, but it further elicits a mutual control motion. Mental and motor events have the same nerve, cortical, and spinal motoneuron substrate. The mental events arising from the motoneuronal system expressed by human language can be closely combined with the unity of the mind-brain-body triad. Impulses outside body are received through a processed sensorineural mechanism resulting in perceptions in the brain association cortex. What the subjects see and hear in idol worship through social media affects their perceptions which, in turn, impact on their sexual orientation.

Within sensory system, each sensory modality (hearing, sight, touching, etc.) is mediated by a particular system in a particular path. The spatial relations that exist within the surface of the peripheral recipient, whether it is a retina (sight), cochlea (hearing), or cutis (palpability), are stored at various levels of the central nervous system. A group of adjacent retinal cells projected onto adjacent thalamic cell groups, which then switched to areas adjacent to the visual cortex [6]. This affects the formation of orientation.

Celebrity worship is a form of a parasocial relationship in which a person becomes obsessed with celebrities [7]. Celebrity worship is an individual's obsessional behavior which always engages in every celebrity's life. It is so popular that it brings into his daily life [5]. When the engagement intensity with celebrity increases, a fan will assume that his idol's celebrity is a close person. The, he will continuously develop his parasocial relationship. The parasocial relationship is an imaginative relationship between fans with a one-way idolized figure, from fans to idols.

According to Maltby et al [5], celebrity worship is divided into three levels below: (1) Entertainment-social level, --that is illustrated by the motivation underlying a fan's active search to a celebrity or a popular person (such as reading the news about the people who are popular, concerning the popular person); (2) Intense-personal level that expresses intensive and compulsive feelings for a celebrity, and is almost close to a fan's obsessive feelings towards a celebrity that become his 
idols, and (3) Borderline pathological level, -- that is a fan's highest level or deepest relationship or engagement with a celebrity; It is indicated with an attitude (such as a willingness to do anything for the sake of celebrity), even though it violates the law.

The study reveals that the higher the shipper fanaticism, the higher the intense homosexual is. This is in contrast to Gooch's opinion that the shoppers or fans who match certain characters of the same sex are generally fans with heterosexual orientation.

A false belief of fantasy will lead a shipper to get used to same-sex relationships, both within his idolizing world and his life around him. Based on the results of interviews with the subject of a shipper with high fanaticism, he stated that since he idolized a couple with the same sex, he imagined that there is a friend or he saw two men who were close friends he became to imagine that both men have a homosexual relationship and he becomes fond of men.

\section{CONCLUSION}

The present research concludes that that the higher the idol fan ship fujoshi and fudanshi the higher homosexual intensity in the K-pop shipper fans. Social media, can be used to express themselves in accordance with the wishes of an individual, but fantasizing the shipper through social media can affect beliefs and change sexual orientation.

\section{REFERENCES}

[1] M.W. Staff, Merriam-Webster's Guide to Punctuation and Style. Merriam-Webster, 1995.

[2] K. Hellekson, K. Busse, Fan fiction and fan communities in the age of the Internet: new essays. McFarland, 2006.

[3] A. Supratiknya, Mengenal perilaku abnormal. Kanisius, 1995.

[4] L.E. McCutcheon, D.D. Ashe, J. Houran, J. Maltby, A cognitive profile of individuals who tend to worship celebrities. The Journal of Psychology, 137(4), 309-322, 2003.

[5] L. Barber, J. Maltby, A. Macaskill, Angry memories and thoughts of revenge: The relationship between forgiveness and anger rumination. Personality and Individual Differences, 39(2), 253-262, 2005.

[6] M. Langen, M.J. Kas, W.G. Staal, H. van Engeland, S. Durston, The neurobiology of repetitive behavior: of mice... Neuroscience \& Biobehavioral Reviews, 35(3), 345-355, 2011.

[7] E. Frederika, M.H. Suprapto, K.L. Tanojo, Hubungan Antara Harga Diri dan Konformitas Dengan Celebrity Worship Pada Remaja Di Surabaya, 2015 . 